\title{
TRITICALE RESISTANCE TO THE MAIN PHYTOPATHOGENIC ORGANISMS OF NORTHWEST REGION OF THE RUSSIAN FEDERATION
}

\author{
L.E. Kolesnikov ${ }^{1}$, E.A. Vlasova $^{1}$, E.Yu. Funtikova ${ }^{2}$, Yu.R. Kolesnikova ${ }^{1}$ \\ ${ }^{I}$ St. Petersburg State Agrarian University, 2, Peterburgskoye sh., St. Petersburg - Pushkin, 196601 Russia \\ e-mail: kolesnikovleoni@rambler.ru \\ ${ }^{2}$ N.I. Vavilov Research Institute of Plant Industry, RAAS, 42-44, ul. Bolshaya Morskaya, St. Petersburg, 190000 Russia
}

Received October 12, 2010

S u m m a ry

The modern triticale varieties have high feed advantages, they have a good tolerance to difficult environments and they are resistant to majority of phytopathogens. For the period of 2005-2006 phytosanitary monitoring for the triticale samples of different ecologo-geographic origin with spring (327 samples) and winter (37 samples) type of development from N.I. Vavilov All-Russian Scientific Research Institute of Plant Growing on the resistance to the basic wheat pathogens of Northwest region of the Russian Federation (brown and yellow rust, wheat leaf blotch, powdery mildew) was carried out. In addition, the authors determine the duration of interphase periods, the height of plants, the mass of 1000 grains. The pathogen of powdery mildew does not develop on samples of triticale. The maximal number of triticale samples, introduced from the European part of the former Soviet Union (Ukraine, Belarus) was characterized by absence of defeat symptoms by brown rust and wheat leaf blotch agents. Pathogenesis of the yellow rust agent was not found on the triticale samples, received from Central Asia, Northern Europe, Australia, South America, Asia and Africa. As was revealed, the greatest degree the attribute of triticale origin influenced on wheat leaf blotch pathogenesis, in the least - on brown and yellow rusts pathogenesis. As was revealed, the criterion of a triticale origin influenced on wheat leaf blotch pathogenesis in the greatest degree, and in the least - on brown and yellow rusts. In the greater degree the plants development type affect the wheat leaf blotch pathogenesis on triticale samples of the Russian selection and in smaller - on triticale samples, received from European part of Former USSR, Northern Europe, East Europe, Central Europe.

Keywords: triticale, cereal crop diseases, leaf rust, yellow rust, wheat leaf blotch, powdery mildew.

Modern varieties of triticale successfully compete with best cultivars of rye, barley, oats, and wheat in yield of grain and green mass, as well as other advantages: high fodder value; ability to grow on poor, flooded, and acidic soils; good tolerance to adverse hibernation conditions and cold snap in spring period; resistance to many phytopathogens (1-5).

The purpose of this work was testing triticale samples of different eco-geographic origin for resistance to major phytopathogens common to the North-West of Russian Federation.

Technique. Observations were conducted in the experimental field of N.I. Vavilov Research and Development Institute of Plant Industry (VIR) in 2005-2006. The material for testing were triticale varieties and hybrids from VIR collection with spring (327 samples) and winter (37 samples) type of development, and quite diverse geographic origin: Russia (Leningrad Oblast, Moscow Oblast, Voronezh Oblast, Rostov Oblast, Krasnodar Krai, Dagestan), European part of the former Soviet Union (FSU) (Ukraine, Belarus), Soviet Central Asia (Tajikistan), Northern Europe (UK, Sweden), Australia, South America (Argentina, Mexico, Brazil, Ecuador, Chile), Central and Southeastern Europe (Poland, Bulgaria, Serbia, Montenegro), Central Europe (France), North America (USA, Canada), Southern Europe (Italy, Spain, Portugal, Greece), Asia (India).

Morphophysiological characters of the samples (duration of interphase periods, plant height, weight of 1000 grains, etc.) were evaluated according to the guidelines (6). Conditional intensity of development of yellow rust was assessed by Peterson's scale (7). Pustules of brown rust were counted at onset of the disease - per leaf, and at further development of lesion - per $1 \mathrm{~cm}^{2}$ of leaf surface. Types of plant responses to yellow and brown rust pathogens were classified following the descriptions $(8,9)$. It was evaluated 20 plants of each sample. Development of leaf spot disease was assessed by comparing the intensity of lesion on leaf surface of 20 plants with illustrated scale of W.O. James (10). Types of responses were determined by a 4-point scale established in the All-Russia Research and Development Institute of Phytopathology (Moscow Oblast, Bolshye Vyazemy) (11).

The data were statistically treated by standard methods using software packages Statistica v. 6.0 and SPSS v. 18.0.

Results. Symptoms of leaf spot disease (Stagonospora nodorum Berk. and Septoria tritici Roberge ex Desm.), brown rust, and yellow rust were observed on flag and pre-flag leaves of triticale samples during the period of phytosanitary monitoring. Powdery mildew wasn't identified on the plants.

Spring and winter triticale samples were separated into groups by their geographic origin in order to pool the data on development and extension of diseases and to analyze the information about types of plants' responses (Table 1).

1. Development $(\mathrm{R}, \%)$ and extension $(\mathrm{P}, \%)$ of phytopathogens on triticale samples of different eco-geographic origin (experimental field, St. Petersburg - Pushkin, 20052006)

\begin{tabular}{|c|c|c|c|c|c|c|c|c|c|c|c|}
\hline \multirow{2}{*}{$\begin{array}{l}\text { Statistical } \\
\text { parameter }\end{array}$} & \multirow{2}{*}{ Origin } & \multirow{2}{*}{$\mathrm{R}, \mathrm{P}$} & \multicolumn{3}{|c|}{ Leaf spot disease } & \multicolumn{3}{|c|}{ Brown rust } & \multicolumn{3}{|c|}{ Yellow rust } \\
\hline & & & FL & PFL & TR & FL & PFL & TR & FL & PFL & TR \\
\hline \multicolumn{12}{|c|}{ Spring form s } \\
\hline $\bar{X}$ & Russia (Leningrad Oblast, & $\mathrm{R}$ & 1.42 & 2.51 & 1.29 & 2.24 & 1.77 & 1.41 & 1.05 & 1.00 & 1.00 \\
\hline$S \bar{x}$ & Moscow Oblast, Voronezh & & 0.05 & 0.13 & 0.33 & 0.11 & 0.52 & 0.33 & 0.13 & 0.00 & 0.33 \\
\hline $\bar{X}$ & Oblast, Dagestan) & $P$ & 43.19 & 47.28 & 0.00 & 34.72 & 20.00 & 0.00 & 16.00 & 10.00 & 0.00 \\
\hline$S \bar{x}$ & & & 0.78 & 0.99 & 0.00 & 1.17 & 3.82 & 0.00 & 2.45 & 9.49 & 0.00 \\
\hline $\bar{X}$ & Europ & $\mathrm{R}$ & 1.62 & 2.12 & 1.25 & 1.60 & 2.51 & 1.50 & 2.56 & 1.00 & 1.50 \\
\hline$S \bar{x}$ & (Ukraine, Belorussia) & & 0.07 & 0.06 & 0.22 & 0.31 & 1.12 & 0.22 & 2.33 & 0.00 & 0.22 \\
\hline $\bar{X}$ & & $P$ & 31.88 & 60.56 & 0.00 & 20.00 & 23.75 & 0.00 & 16.67 & 10.00 & 0.00 \\
\hline$S \bar{x}$ & & & 1.61 & 2.09 & 0.00 & 2.68 & 4.45 & 0.00 & 3.29 & 9.49 & 0.00 \\
\hline $\bar{X}$ & Soviet Central Asia (Tajiki- & $\mathrm{R}$ & 5.00 & 0.00 & 1.00 & 0.00 & 0.00 & 0.00 & 0.00 & 0.00 & 0.00 \\
\hline$S \bar{x}$ & stan) & & 0.32 & 0.00 & 0.00 & 0.00 & 0.00 & 0.00 & 0.00 & 0.00 & 0.00 \\
\hline $\bar{X}$ & & $P$ & 10.00 & 0.00 & 0.00 & 0.00 & 0.00 & 0.00 & 0.00 & 0.00 & 0.00 \\
\hline$S \bar{x}$ & & & 3.16 & 0.00 & 0.00 & 0.00 & 0.00 & 0.00 & 0.00 & 0.00 & 0.00 \\
\hline $\bar{X}$ & Nortl & $\mathrm{R}$ & 4.00 & 1.00 & 1.50 & 1.83 & 2.17 & 1.67 & 0.00 & 0.00 & 0.00 \\
\hline$S \bar{x}$ & Sweden) & & 0.67 & 0.00 & 0.40 & 0.75 & 0.60 & 0.33 & 0.00 & 0.00 & 0.00 \\
\hline
\end{tabular}




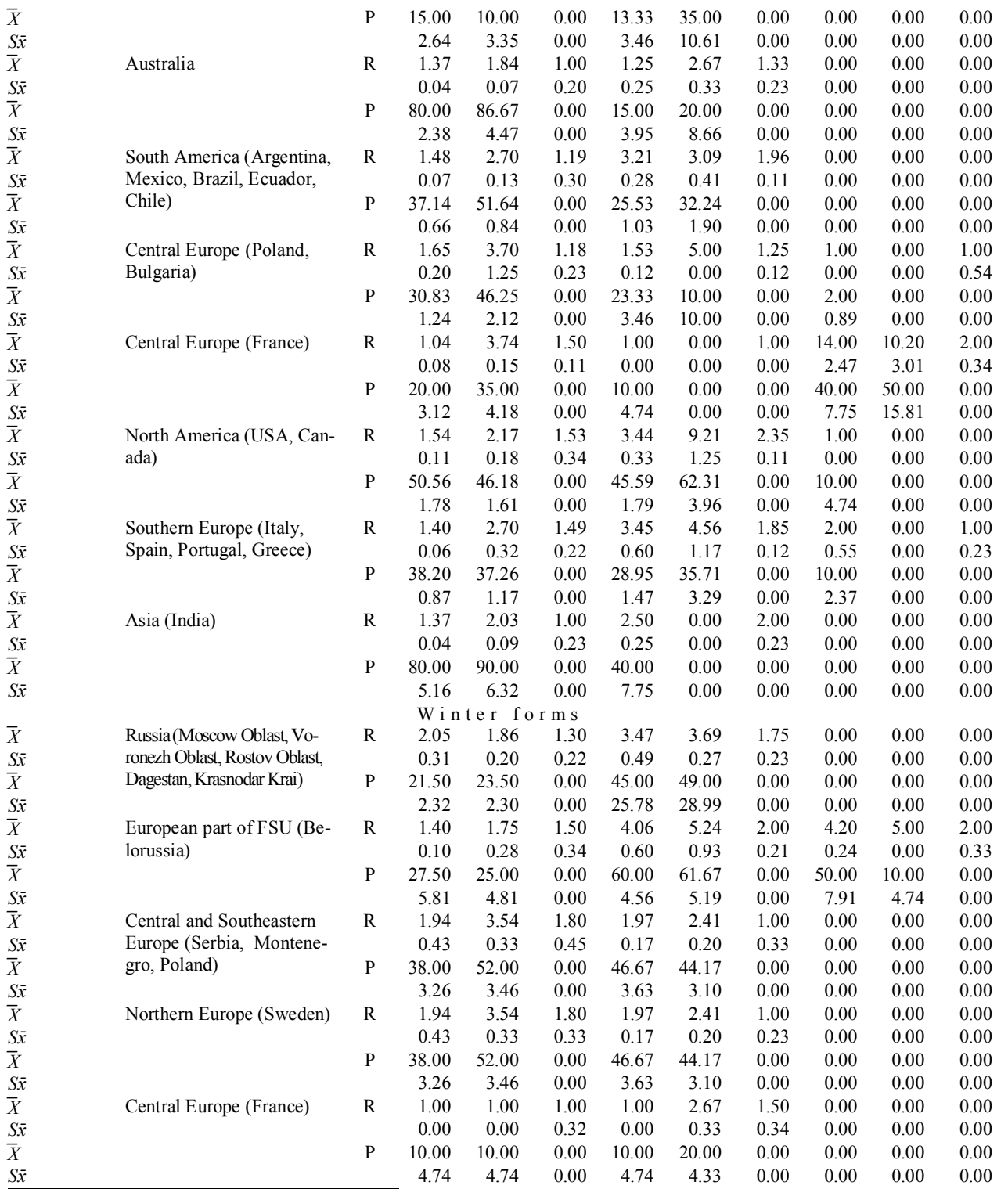

$\mathrm{N}$ o t e.$X$ - mean, $S \bar{x}$ - standard error of mean, FL - flag leaf, PFL - pre-flag leaf, TR - type of response.

During the period of research the symptoms of brown rust were absent in $75 \%$ spring triticale forms of Russian origin (Ukro, k-3644; GL 29/26, k-2873; etc.). 82.69 \% samples from the European part of FSU were not affected by the disease (S3 3/2, k-1509; Prim 10/1, k-1511; KhL 16, k-1716; Sokol kharkovskij, k-3542; Zhavoronok kharkovskij, k-609519; Khlebodar kharkovskij, k609520; etc.), as well as 78.57 \% samples from the Northern Europe (Taurus, k-3593; HT 76-13, k-1084; HT 76-19, k-1806; etc.); $77.48 \%$ - from the Central and Southeastern Europe (Mexitol, k-3504; Jago, k-2044; Maja, k-2045; Gabo, k-3722; Migo, k-3726; etc.); $75.00 \%$ - from the Central Europe (Clervix, k-1194; Clercal, k-1195; etc.); $72.73 \%$ — from Australia (Satu, k-828; Dua, k829; Tyalla, k-830; Grow Quick, k-1213; etc.); 62.71 \% — from the South Europe (Thisvi, k-2110; Tritibat, k-1197; Grace, k1200; Cirro, k-1201; etc.); 62.02\% — from the South America (Almeria 83, k-3511; Caguan 3, k-3517; Fahad 8-2, k-3522; Sandro, k-3532; etc.); $22.73 \%$ — from the North America (N 13, k-126; Welsh, k-1218; AC Certa, k-3592; etc.).

Leaf spot disease wasn't observed in 73.08 \% samples from the European part of FSU (C3 3/2, k-1509; Prim 10/1, k-3511; KhL 16, k-1716; Aist Kharkovskij, k-2778; etc.); in 72.73 \% — from Australia (Satu, k-828; Dua, k-829; Jenking 203, k-1212; etc.); $71.43 \%$ - from the Northern Europe (Taurus, k-3593; HT 76-13, k-1804; etc.); $65.11 \%$ — from Russia (Ukro, k-3644; Dagvo, k3645; GL 29/26, k-2873; Zolotoy grebeshok, k-3677; SPTG 15-2, k-3126; etc.); $45.74 \%$ — from the South America (Jenking 203, k1212; Tricepiro 66/93, k-3474; Almeria 83, k-3511; etc.); $37.29 \%$ — from the Southern Europe (Thisvi, k-2110; Tritibat, k-1197; Cirro, k-1201; etc.); $33.33 \%$ — from the Central and Southeastern Europe (Maja, k-2045; Wanad, k-3723; Kargo, k-3724; etc.); 25 $\%$ - from the Central Europe (Clercal, k-1195; etc.); $22.73 \%$ — from the South America (N 13, k-126; OAC Triwell, k-1028; AC Alta, k-3632; etc.).

Symptoms of yellow rust were absent in $100 \%$ samples from the Soviet Central Asia, Northern Europe, Australia, South America, Asia, and Africa (Umar, k-3269; Taurus, k-3593; etc.), in 95.5 \% — from the North America (Carman, k-1027; OAC Triwell, k-1028; etc.); 93.2\% — from the Southern Europe (Thisvi, k-2110; Tritibat, k-1197; etc.); $94.23 \%$ - from the European part of FSU (Prim 10/1, k-1511; SL 20, k-1718; etc.); $94.4 \%$ — from the Central and Southeastern Europe (Mexitol, k-3504; Jago, k-2044; etc.); $75 \%$ — from the Central Europe (Clercal, k-1195, etc.); $96.13 \%$ — from Russia (Skoryj 2, k-3498; PRAG 517, $\mathrm{k}-3826$; etc.). The last group was insignificantly affected by the pathogen $\left(\mathrm{R}_{\mathrm{y}}\right)-$ samples Ukro, $\mathrm{k}-3644\left(\mathrm{R}_{\mathrm{y}}=0.6 \pm 0.06 \%\right)$; GL 116 , $\mathrm{k}-2876\left(\mathrm{R}_{\mathrm{y}}=0.5 \pm 0.05 \%\right)$; PRAG 103, k-426 ( $\left.\mathrm{R}_{\mathrm{y}}=0.5 \pm 0.01 \%\right)$; PRAG 501, k-3608 $\left(\mathrm{R}_{\mathrm{y}}=0.5 \pm 0.02 \%\right)$.

Among the tested winter triticale forms, brown rust didn't affect $50 \%$ samples from the Central and Southeastern Europe (Auriac, i-63995; NS-Triticale, i-64532; Prado, i-63611; Ugo, i-63614; etc.); 38.89 \% — from Russia (2-oh-AD-5136, i-14277; Vodoley, k-36; Bard, k-i-14832; Valentin, i-14568; Mudrets, i-14569; PRAG 24; PRAG $24 \times$ PRAG 418; etc.); in $33 \%$ samples from the 
European part of FSU (Kastus, i-65517, etc.) leaf spot disease wasn't observed on $16.57 \%$ samples from Russia (1-oh-AD-4679, i1426; 2-oh-AD-5136, i-14277; PRAG $24 \times$ PROG 418; etc.); $50 \%$ - from the Southeastern Europe (NS-Triticale, i-64532; Prado, i63611; Marko, i-63613; etc.) and the Northern Europe (SW-Falmozo, i-63365, etc.). In turn, symptoms of leaf spot disease were found in all triticale forms introduced from the European part of FSU and the Central Europe. Yellow rust was revealed on the only sample (Mikhas, i-6335) from the European part of FSU: $\mathrm{R}_{\mathrm{yr}}=4.6 \pm 0.2 \% ; \mathrm{P}_{\mathrm{yr}}$ (extension of the disease) $=30 \pm 4.6 \%$.

The picture shows results of ranking the tested spring triticale forms by resistance to the abovementioned pathogens. Samples from Australia (Satu, k-828; Dua, k-829; Tyalla, k-830; etc.) manifested the minimum development of leaf spot disease on flag and pre-flag leaves $\left(\mathrm{R}_{\mathrm{s}}=1.6 \pm 0.04 \%\right)$ along with quite significant extension of the disease $\left(\mathrm{P}_{\mathrm{s}}=83.33 \pm 1.91 \%\right)$. The most severe development of this infection $\left(\mathrm{R}_{\mathrm{s}}=5.0 \pm 0.32 \%\right)$ exhibited spring forms from the Soviet Central Asia (Tajikistan) though its extension was the lowest $\left(\mathrm{P}_{\mathrm{s}}=10.00 \pm 3.16 \%\right)$. Samples from the South America (Carman, k-1027; OAC Triwell, k-1028; Welsh, k-1218; etc.) showed the greatest development and extension of brown rust $\left(\mathrm{R}_{\mathrm{b}}=6.32 \pm 0.65\right.$ pustules per leaf, $\left.\mathrm{P}_{\mathrm{b}}=53.95 \pm 2.17 \%\right)$ (Fig., B). Maximum development $\left(\mathrm{R}_{\mathrm{y}}=12.10 \pm 1.94 \%\right)$ and extension $\left(\mathrm{P}_{\mathrm{y}}=45.00 \pm 8.80 \%\right)$ of yellow rust were recorded in triticale samples from the Central Europe (Fig., B).

Assessing these data by crosstabs suggested origin of a sample as the major factor affecting pathogenesis of leaf spot disease $\left(\chi^{2}=979.13 ; p=0.012\right.$; Kramer's value $\left.\mathrm{V}=0.713\right)$, which was also confirmed by data on extension of the disease $\left(\chi^{2}=323.5\right.$, $\mathrm{p}=0.038, \mathrm{~V}=0.389)$. This factor caused the minimum (low-reliable) effect on development of brown rust $\left(\chi^{2}=524.08 ; \mathrm{p}=0,100 ; \mathrm{V}=\right.$ $0.68)$ and yellow rust $\left(\chi^{2}=20.58, \mathrm{p}=0,420, \mathrm{~V}=0.567\right)$, as it could be seen from extension of these diseases (brown rust $-\chi^{2}=$ $15.87, \mathrm{p}=0.044, \mathrm{~V}=0.753$; yellow rust $\left.-\chi^{2}=148.27, \mathrm{p}=0.989, \mathrm{~V}=0.335\right)$.
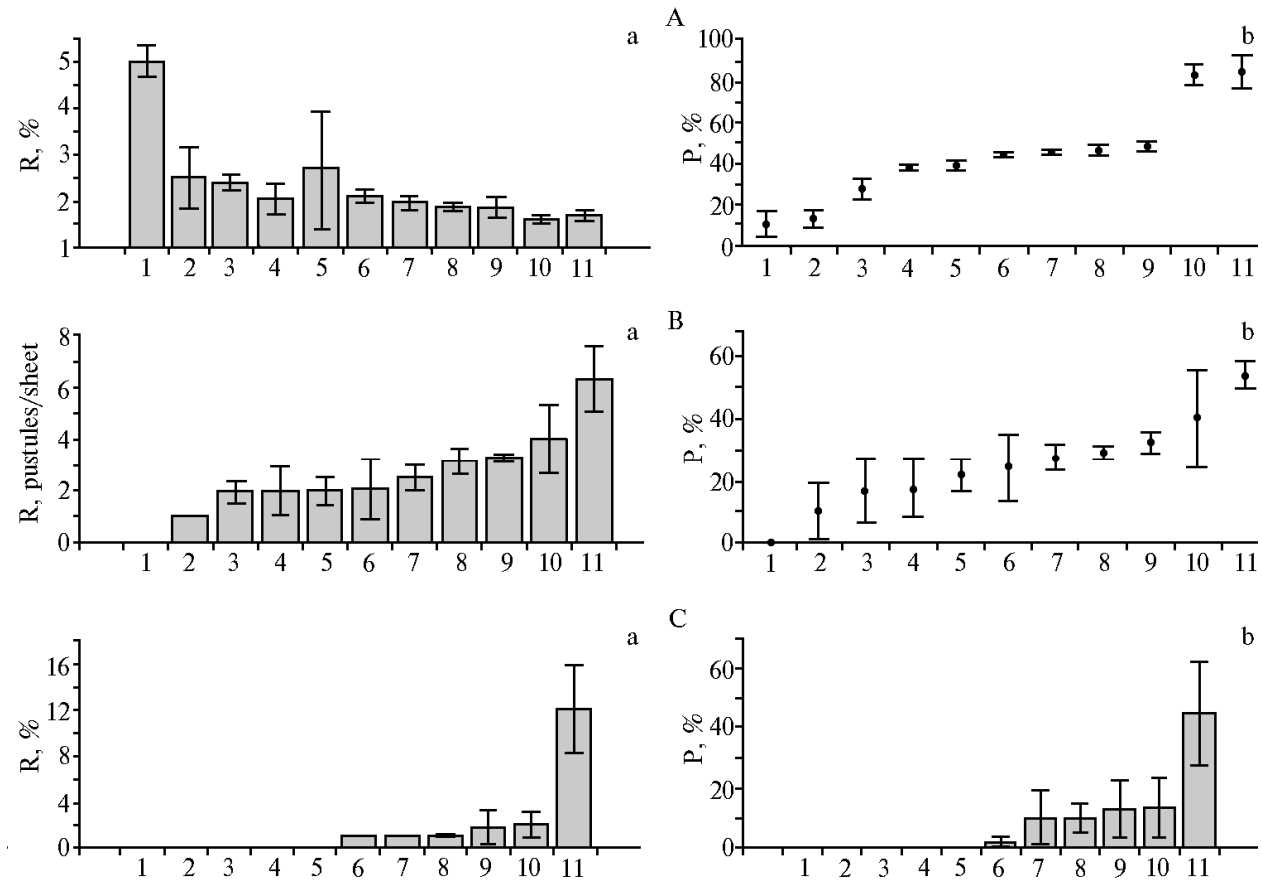

C

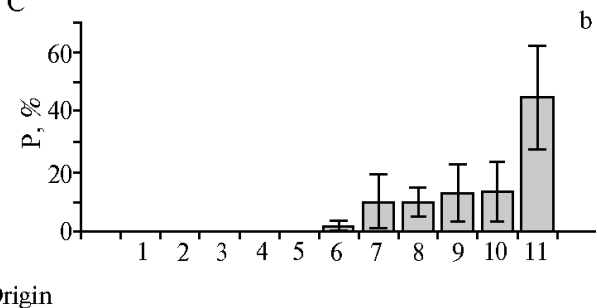

Development (R; a) and extension ( $P$; b) of leaf spot disease (A), brown rust (B), and yellow rust (C) on spring triticale forms of different eco-geographic origin: 1 - Australia, 2 - Asia, 3 - North America, 4 European part of FSU, 5 - Russia, 6 - Southern Europe, 7 - South America, 8 - Central Europe, 9 - Northern Europe, 10 - Central and Southeastern Europe, 11 - Soviet Central Asia (experimental field, St. Petersburg - Pushkin, 2005-2006)

The analysis of correlations between the expression of leaf spot disease, brown rust, and yellow rust with type of plant development (winter or spring), as well as their origin has shown that the type of development caused the greatest influence on pathogenesis of leaf spot disease on triticale samples of Russian origin $\left(\chi^{2}=67.00 ; p=0.003\right)$ and the least (low reliable) - on samples from the European part of FSU $\left(\chi^{2}=15.00, p=0.182\right)$, the Northern Europe $\left(\chi^{2}=5.00, p=0.132\right)$, the Southeastern Europe $\left(\chi^{2}=18.00, p=0.158\right)$ and the Central Europe $\left(\chi^{2}=4.00, p=0.261\right)$. There was observed a similar trend for leaf rust pathogen: the type of development provided the highest influence on development of brown rust on Russian samples $\left(\chi^{2}=30.94, p=\right.$ 0.043). Using parametric and non-parametric methods it was revealed a negative relationship between the development of brown rust and leaf spot disease (Pearson's correlation $r=-0.158$, Kendall's tau-b $\tau=-0.152$, Spearman's coefficient $\rho=-0.214$ ); brown and yellow rust $(r=-0.28 ; \tau=-0.177 ; \rho=-0.219)$.

Applying the diagonal matrix of Pearson's correlation coefficients (Table 2) allowed to establish a reliable positive relationship between the rate of development of leaf spot disease and duration of the period (days) before the onset of earing $(\mathrm{r}=0.62$ at $\mathrm{p}=0.001)$ and complete earing in spring triticale forms $(r=0.63$ at $\mathrm{p}=0.001)$. It should be noted that development of leaf spot disease and brown rust were increasing correspondingly to reduce in plant height and caused the decline in weight of 1000 grains. 
phytopathogens and morphobiological characters of investigated spring triticale

forms (experimental field, St. Petersburg - Pushkin, 2005-2006)

\begin{tabular}{|c|c|c|c|c|}
\hline Disease & $\begin{array}{l}\text { Time before the on- } \\
\text { set of earing }\end{array}$ & $\begin{array}{l}\text { Time before com- } \\
\text { plete earing }\end{array}$ & Plant height & $\begin{array}{l}\text { Weight of } 1000 \\
\text { grains }\end{array}$ \\
\hline Leaf spot disease & $0.62(\mathrm{p}=0.001)^{\mathrm{r}}$ & $0.63(\mathrm{p}=0.001)^{\mathrm{r}}$ & $-0.09(\mathrm{p}=0.70)$ & $-0.32(\mathrm{p}=0.13)$ \\
\hline Brown rust & $-0.15(\mathrm{p}=0.48)$ & $-0.18(\mathrm{p}=0.42)$ & $-0.24(\mathrm{p}=0.28)$ & $-0.36(\mathrm{p}=0.047)^{\mathrm{r}}$ \\
\hline
\end{tabular}

Thus, bio-geographic features of triticale significantly affect pathogenesis of leaf spot disease, brown and yellow rust on these crops. The highest number of spring triticale forms with a broad-spectrum (field) resistance to these pathogens was found among the samples from the European part of the former Soviet Union. For winter triticale forms, the maximum amount of resistant forms was revealed among samples from the Central and Southeastern Europe. Results of this research can be used in breeding work aimed at creation of triticale varieties and hybrids adapted to environmental conditions in the North-West of Russia.

\section{REFERENCES}

1. Gavrilova O.M., Mishkina V.A. Sel'skokhozyaistvennaya Biologiya [Agricultural Biology], 1985, 4: 59-62.

2. Goncharov S.V., Shevchenko V.E. Sel'skokhozyaistvennaya Biologiya[Agricultural Biology], 2000, 1: 7-20.

3. Merezhko A.F. Tezisy dokladov II Vavilovskoi mezhdunarodnoi konferentsii «Geneticheskie resursy kul'turnykh rastenii. Sostoyanie, problemy, perspek-

tivy»[Abstracts of Papers II Int. Vavilov Conference «Genetic Resources of Cultivated Plants: Current State, Problems, and Prospects»]. St. Petersburg, 2007: 541-543. 4. Mikhailova L.A., Merezhko A.F., Funtikova E.Yu. Doklady RASKHN, 2009, 5: 27-29.

5. Tyryshkin L.G., Kurbanova P.M., Kurkiev K.U., Sarukhanov I.G., Kurkiev U.K.Zashchita i karantin rastenii, $2008,10: 25$.

6. Merezhko A.F., Udachin R.A., Zuev V.E., Filotenko A.A., Serbin A.A., Lyapunova O.A., Kosov V.YU., Kurkiev U.K., Okhotnikova T.V., Navruzbekov N.A., Boguslavskii R.L., Abdullaeva A.K., Chikida N.N., Mitrofanova O.P., Potokina S.A. Popolnenie, sokhranenie v zhivom vide i izuchenie mirovoi kollektsii pshenitsy, egilopsa i tritikale: metodicheskie ukazaniya [Guidelines on Replenishing and Living Maintenance of the World Collection of Wheat, Aegilops, and Triticale]. St. Petersburg, 1999: 32-35.

7. Geshele E.E. Osnovy fitopatologicheskoi otsenki v selektsii rastenii[Fundamentals of Phytopathological Estimation in Plant Breeding]. Moscow, 1978.

8. Gassner G., Straib W. Die Bestimmung der hiologischen Rassen des Weizengelbrostes (P. glumarum f. sp. tritici Eriks. et Henn.). Arbeiten Biol.Reichsanstalt Land und Forstwirtschalt, 1932, 20: 141.

9. Mains E.B., Jackson H.C. Physiologic specialisation in leaf rust Puccinia triticina Erikss et Henn. Phytopathology, 1926, 16: 89-120.

10. James W.O. An illustrated series of assessment for plant diseases preperation and usage. Can. Plant Dis. Surv., 1971, 51(2): 36-55.

11. Kolesnikov L.E., Vlasova E.A., Vinogradov A.A. Sel'skokhozyaistvennaya Biologiya [Agricultural Biology], 2009 , 5: 90-93. 